
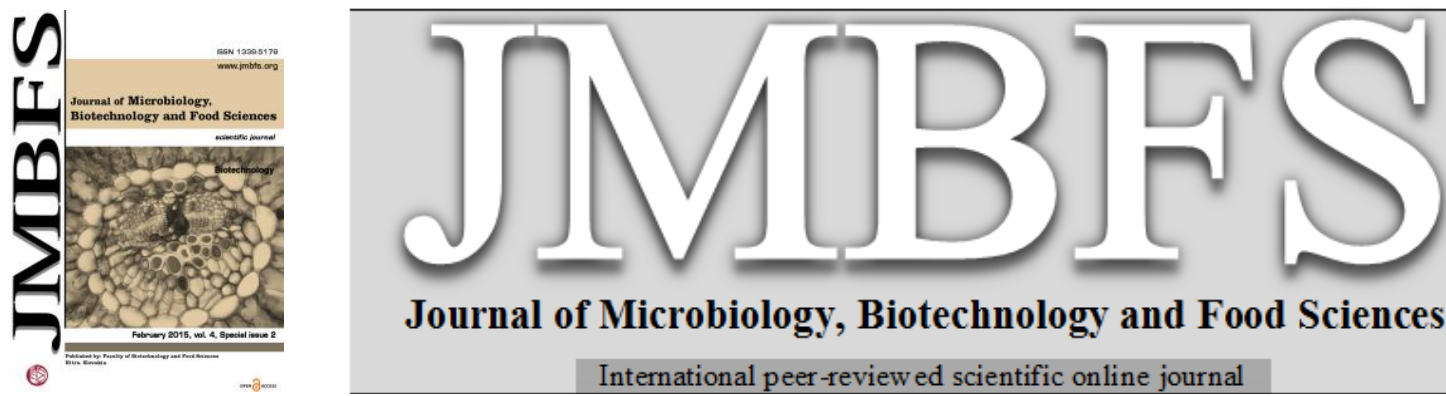

Journal of Microbiology, Biotechnology and Food Sciences

International peer-review ed scientific online journal

\title{
ASSOCIATIONS BETWEEN SNPS IN BOVINE ESTROGEN RECEPTOR GENE AND PRODUCTION TRAITS IN HOLSTEIN CATTLE
}

\author{
Nina Moravčíková*, Anna Trakovická, Alica Navrátilová, Rudolf Nádaský
}

Address(es): Ing. Nina Moravčíková, PhD.

Slovak University of Agriculture in Nitra, Department of Animal Genetics and Breeding Biology, Tr. A. Hlinku 2, 94976 Nitra, The Slovak Republic

*Corresponding author: nina.moravcikova1@gmail.com

doi: 10.15414/jmbfs.2015.4.special2.83-85

\section{ARTICLE INFO}

Received 12. 12. 2014

Revised 17. 12. 2014

Accepted 13. 1.2015

Published 2. 2. 2015

\section{Regular article}

open 2 access

\begin{abstract}
The aim of this study was to determine allelic and genotypic frequency of two SNPs in ER $\alpha$ gene and evaluate the associations between $E R \alpha$ genetic variants and milk production traits in Holstein cattle. Analysis of the molecular mechanisms involved in the regulation of reproduction in connection with milk production and followed genotyping of the individuals with optimal genetic potential may facilitate the animal selection in dairy cattle farms. Genomic DNA was obtained in total from 150 hair root samples of Holstein cows. Two polymorphic sites in 5'region on ER $\alpha$ gene (BTA6) were analysed. Genotyping of animals was carried out by PCR-RFLP method using $S n a \mathrm{BI}$ and $B g l \mathrm{I}$ restriction endonucleases. After restriction analyses was detected in population the presence of two ERa/SnaBI (GG, AG), and three ERa/BglI genotypes (GG, AG, AA). The highest proportion was found for individuals with $E R \alpha / S n a B I \mathrm{GG}(85 \%)$ and $E R \alpha / B g l I$ AA ( $83 \%)$ genotypes. The missing of $E R \alpha / S n a B I$ AA genotype was reflected to the higher distribution of $\mathrm{G}$ allele $(0.92 \pm$ $0.02)$. For the $E R \alpha / B g l I$ polymorphism was observed the higher frequency of A allele $(0.91 \pm 0.02)$. The differences between observed and expected genotype frequencies caused the deviations from HWE in locus $E R \alpha / S n a B I$. The statistical analyses of $E R \alpha$ genotypes effect on milk production traits was performed with linear models (GLM procedure). Based on the selected effect we were able to estimate the variability of analyzed traits on $80 \%$. The $E R \alpha / S n a B I$ and $E R \alpha / B g I I$ genotypes affected the variability of milk, protein and fat yield only non-significant $(\mathrm{P}>0.05)$.
\end{abstract}

Keywords: $E R \alpha$ gene, cattle, milk production, polymorphisms

\section{INTRODUCTION}

Due to the low heritability of some production traits can be decreased the response of animals phenotypic selection. One of the possibilities for resolving this situation may be use of marker assisted selection that is based on analyses of QTLs and mutations associated with physiological functions (Zahmatkesh $\boldsymbol{e t}$ al., 2011). Genetic background of quantitative traits can be determined by detection of polymorphisms located in candidate genes as markers which product take part in physiological processes (Kmieć et al., 2002). The estrogen and its receptors genes are considered as candidate genes for reproduction, functional and production traits in farm animals, including cattle (Szreder and Zwierchowski, 2004a).

In mammals, estrogens affect not only reproduction but also growth, differentiation and function of tissues including mammary gland, uterus, ovaries and testes. This hormone increase the proliferation of uterus epithelial cells together with mammary gland cells (Li et al., 2006). Moreover, the estrogens regulate secondary sexual characteristics and have crucial role in milk synthesis, postnatal physiology and also in pathology of female reproductive organs (Rybaczyk et al., 2005). Cellular activity is regulated by interaction between estrogens and the specific intracellular receptor proteins. Active forms of estrogens constitute an intracellular liphopilic ligand for the nuclear estrogen receptors $(E R)$ that are proteins regulating expression of genes (Szatkowska $\boldsymbol{e}$ al., 2011). Estrogen receptors are transcription factors that are capable to regulate the transcription of target genes after binding of proper ligand (17 $\beta$ estradiol). At first the receptor-steroid complex takes an active form after entry the cell nucleus and then it binds to estrogen responsive elements in promoter regions of estrogen target genes which leads to increase or decrease in gene transcription (Zahmatkesh et al., 2011). The two known isoforms of $E R$ s ( $\alpha$ and $\beta$ ) are coded by a separate gene (Szreder et al., 2011). Most tissues of female reproductive organs express both $\alpha$ and $\beta$ isoforms, which then play important role in mediation of estrogen actions in particular tissue. Generally, both $E R$ isoforms are expresses mainly in female and male reproductive organs, but a high expression was found also in liver, lungs, mammary gland, kidneys, pituitary gland brain and stomach (Szreder and Zwierzchovski, 2004b). The bovine $E R C$ gene has been localized on BTA 6 and consists of 8 exons. The 5' region of ERa has additional non-coding exons that coding transcripts of different length with information about 5'UTR regions (Szatkowska et al., 2011; Szreder et al., 2011). In the present study were analyzed by PCR-RFLP two polymorphic sites in 5 'region of $E R \alpha$ gene which were previously identified by Szreder and Zwierchowsky (2004a): $\mathrm{A} / \mathrm{G}$ transition within a promoter for exon $\mathrm{C}$ at position -2429 (restriction enzyme $B g l \mathrm{l}$ ) and A/G transition at position -976 (restriction enzyme SnaBI).

The aim of the present study was to determine allelic and genotypic frequency of two SNPs in $E R \alpha$ gene and evaluate the associations between $E R \alpha$ genetic variants and milk production traits in Holstein cattle.

\section{MATERIAL AND METHODS}

The total number of hair root samples was obtained from 150 Holstein cows originating from two farms in Slovakia with high milk production. Genomic DNA was extracted from each sample according to Gábor et al. (2009). Concentration of genomic DNA was evaluated by the spectrophotometric measurements by optical density at wave length of $260 \mathrm{~nm}$. Genotyping of animals was performed using PCR-RFLP analyses. A $340 \mathrm{bp}(E R \alpha / S n a B I)$ and $242 \mathrm{bp}(E R \alpha / B g l I)$ fragments in 5'region of $E R \alpha$ gene was amplified by PCR using forward and reverse primers according to Szreder $\boldsymbol{e t}$ al. (2007) and Szreder and Zwierzchovski (2004b), respectively. Subsequently the PCR products were digsted for detection of animal genotypes with $1 \mu 1$ of FastDigest SnaBI and BglI endonucleases (Fermentas). Both PCR and restriction fragments were separated by horizontal electrophoresis in $3 \%$ agarose gels $(140 \mathrm{~V}$ for 30 min) and visualized under UV light.

The frequency of alleles and genotypes of $E R \alpha$ gene were calculated according to Yeh et al. (2000) and examined for deviation from Hardy - Weinberg equilibrium (HWE) using Chi-square $\left(\chi^{2}\right)$ test. All statistical analyses in dataset containing genotyping data and information about milk production of evaluated individuals were carried out by SAS Enterprise Guide 4.2 software (SAS Institute Inc., 2009). The effects of $E R \alpha$ genotype on milk production traits (milk, protein and fat yield) were tested by parametric t-test from for significant deviation from zero. The analysis of associations between the SNPs and production traits were performed using GLM (General Linear Model) procedure with the following model:

$\mathbf{Y}_{\mathrm{ijk} k m n o}{ }_{1,2,3}=\mathbf{G}_{\mathrm{i}}+\mathbf{B T}_{\mathrm{j}}+\mathrm{S}_{\mathrm{k}}+\mathbf{B}_{\mathrm{l}}+\mathbf{A F C}_{\mathrm{m}}+\mathbf{C I}_{\mathrm{n}}+\mathbf{L D}_{\mathrm{o}}+\mathrm{e}_{\mathrm{ijk} k \mathrm{mmo}}$

where: $\quad \mathrm{Y}_{\mathrm{ijk} \text { lmn }}{ }_{1,2,3}$ - milk, protein and fat yield, $\mathrm{G}_{\mathrm{i}}$ - effect of $E R \alpha / S n a B I$ and ERa/BglI genotypes, $\mathrm{BT}_{\mathrm{j}}-$ effect of breed type, $\mathrm{S}_{\mathrm{k}}-$ effect of sire, $\mathrm{B}_{1}-$ effect of breeder, $\mathrm{AFC}_{\mathrm{m}}-$ effect of age at first calving, $\mathrm{CI}_{\mathrm{n}}-$ effect of calving interval, $\mathrm{LD}_{\mathrm{o}}$ - effect of lactation days, $\mathrm{e}_{\mathrm{ijkl} \text { mno }}$ - random error. 


\section{RESULTS AND DISCUSSION}

Only two genotypes for $E R \alpha / S n a B I$ and three for $E R \alpha / B g l I$ polymorphic sites were identified in the analysed population of Holstein cows (Tab. 1). The highest proportion was found for individuals with $E R \alpha / S n a B I$ GG and $E R \alpha / B g l I$ AA genotypes. The low frequency of $E R \alpha / S n a B I$ AG genotype and missing of AA genotype was reflected to the higher distribution of $G$ allele. Despite that in second analysed polymorphic site $(E R \alpha / B g l l)$ was detected all three genotype, the higher frequency was observed for A allele. The Hardy-Weinberg equilibrium was identified only in locus $E R \alpha / B g l I$. The differences between observed and expected genotype frequencies have caused the deviations from HWE.

The absence of homozygous ER $\alpha / S n a B I$ AA genotype and prevalence of $\mathrm{G}$ allele was reported for several dairy cattle breeds (Szreder et al., 2007), in Polish black and white cattle (Jedrzejczak et al., 2011), and in Holstein-Frisian cattle (Szatkowska et al., 2011).

The ER $/$ Bgll polymorphism was analysed not only in dairy but also in beef cattle breeds, include Holstein-Frisian, Charolais, Limousine, Simmental, Aberdeen Angus and Hereford (Szreder and Zwierchowski, 2004a). Similar higher frequency of A allele was found in Holstein catte by Szatkowska et al. (2011) and Zahmatkesh et al. (2012).
Table 1 Observed frequency of alleles and genotypes of $E R \alpha$ makers

\begin{tabular}{|c|c|c|c|c|c|c|}
\hline \multirow{2}{*}{ SNP } & \multicolumn{3}{|c|}{ Genotype frequency } & \multicolumn{2}{|c|}{ Allele frequency } & \multirow[t]{2}{*}{$\chi^{2}$ test } \\
\hline & GG & AG & $\mathbf{A A}$ & G & $\mathbf{A}$ & \\
\hline$E R a / S n a B I$ & 0.833 & 0.167 & - & $\begin{array}{c}0.917 \pm \\
0.016 \\
\end{array}$ & $\begin{array}{c}0.083 \pm \\
0.016\end{array}$ & $0.534^{-}$ \\
\hline$E R \alpha / B g l I$ & 0.027 & 0.127 & 0.846 & $\begin{array}{c}0.090 \pm \\
0.017\end{array}$ & $\begin{array}{c}0.910 \pm \\
0.017\end{array}$ & $\begin{array}{c}0.021 \\
+\end{array}$ \\
\hline
\end{tabular}

${ }^{+} \mathrm{P}>0.05,{ }^{-} \mathrm{P}<0.05$

Basic statistical measurements of evaluated milk production traits analysed for second lactation are described in table 2 . The analyses of associations between SNPs in $E R \alpha$ gene and milk production was based mainly on linear models. First, the effects of SNPs were estimated by parametric t-test, but in this procedure were included only genotype effects. Subsequently the GLM models were used and fixed effects of breed type, sire, breeder, age at first calving and days in lactation were selected. Based on these factors we were able to determine the variability of production traits in selected individuals in average on $80 \%$. Both SNPs in $E R \alpha$ gene influenced the variability of milk, protein and fat production only non-significant. Though the differences between animals with different $E R \alpha / S n a B I$ genotype indicated the potential positive effect of GG genotype on production traits, the analyses haven't confirmed these assumptions. The statistically significance was found only for effects of sire $(\mathrm{P}<0.05)$, breeder $(\mathrm{P}<0.01)$ and days in lactation $(\mathrm{P}<0.0001)$.

\begin{tabular}{cccccc}
\multicolumn{2}{c}{ Table 2 Basic statistical variation measurements of milk production traits } \\
\hline Trait & n & mean & SD & min & max \\
\hline Milk yield $(\mathrm{kg})$ & & 10441.68 & 5148.68 & 412.00 & 26859.00 \\
Protein yield $(\mathrm{kg})$ & 149 & 326.47 & 163.77 & 10.00 & 902.00 \\
Fat yield $(\mathrm{kg})$ & & 348.56 & 167.79 & 16.00 & 770.00 \\
\hline
\end{tabular}

Table 3 The effect of $E R \alpha / S n a B I$ and $E R \alpha / B g l I$ genotypes on milk production traits in analyzed cows

\begin{tabular}{|c|c|c|c|c|c|c|c|c|c|c|c|}
\hline \multirow{3}{*}{ Trait } & \multicolumn{4}{|c|}{$E R \alpha / S n a B I$} & \multicolumn{6}{|c|}{$E R a / B g l I$} & \multirow{3}{*}{$\begin{array}{l}\text { Factors } \\
\text { breed type } \\
\text { sire* }\end{array}$} \\
\hline & \multicolumn{2}{|r|}{ GG } & \multicolumn{2}{|r|}{$\mathbf{A G}$} & \multicolumn{2}{|r|}{ GG } & \multicolumn{2}{|r|}{ AG } & \multicolumn{2}{|r|}{$\mathbf{A A}$} & \\
\hline & n & mean \pm SD & n & mean \pm SD & $\mathbf{n}$ & mean \pm SD & n & mean \pm SD & n & mean \pm SD & \\
\hline \multirow{2}{*}{ MY } & & $10321.62 \pm$ & \multirow{4}{*}{19} & 10352.84 & \multirow{4}{*}{4} & 13325.00 & \multirow{4}{*}{25} & 9205.64 & \multirow{4}{*}{123} & 10650.93 & \multirow{4}{*}{$\begin{array}{l}\text { breeder** } \\
\text { age at first calving } \\
\text { calving interval } \\
\text { lactation days*** }\end{array}$} \\
\hline & & 5341.34 & & \pm 4035.27 & & \pm 3195.74 & & \pm 5010.02 & & \pm 5161.87 & \\
\hline PY & 125 & $\begin{array}{c}321.67 \pm \\
169.48\end{array}$ & & $\begin{array}{c}324.00 \\
\pm 123.26\end{array}$ & & $\begin{array}{c}434.25 \\
\pm 112.70 \\
\end{array}$ & & $\begin{array}{c}291.08 \\
\pm 164.33 \\
\end{array}$ & & $\begin{array}{c}331.91 \\
\pm 162.95 \\
\end{array}$ & \\
\hline FY & & $\begin{array}{c}341.94 \pm \\
171.31\end{array}$ & & $\begin{array}{c}358.74 \\
\pm 146.14\end{array}$ & & $\begin{array}{c}449.50 \\
\pm 118.35\end{array}$ & & $\begin{array}{c}313.24 \\
\pm 177.02\end{array}$ & & $\begin{array}{c}353.87 \\
\pm 165.14\end{array}$ & \\
\hline
\end{tabular}

Analysis of the molecular mechanisms involved in the regulation of reproduction in connection with milk production and followed genotyping of the individuals with optimal genetic potential may facilitate the animal selection in dairy cattle farms. The gene encoding estrogen receptor $\alpha$ was selected for present study based on its physiological functions which were demonstrated in many previous reported studies (Clarke, 2000; Jakimiuk et al., 2007). This specific intracellular protein regulate by interaction with estrogens the activity of different cells (development of mammary gland, growth and proliferation of ovary and testes cells) and therefore $E R \alpha$ gene can be considered as candidate for reproduction and also production traits in livestock (Szreder and Zwierchowski, 2004a). Both analysed SNPs in this study (SnaBI and BglI) was previously investigated in association with milk performance (Zahmatkesh et al., 2011; Zahmatkesh et al., 2012; Jedrzejczak et al., 2011, Szreder et al., 2011) However no relationship of these SNPs with milk production was detected. The assumption of the involvement of $E R \alpha$ gene polymorphisms in milk production had resulted from the expression in bovine mammary epithelial cells. One possibility explaining our results can be the localization of SNPs in the 5'noncoding region of $E R \alpha$ gene when these mutations may affect only other adjacent mutations. Because the estrogens influence the secretion of growth hormone and leptin, the transcription factors can affect the expression of their receptors. The interaction of transcription factors in part of estrogen $\alpha$ receptor causes probably that estrogen to have influence on special parts of genome with changes the milk fat, without changing the milk and protein yield (Zahmatkesh et al., 2011)

\section{CONCLUSION}

In recent years most of the researches were focused on identification of genetic markers located within economically important genes and on their applying to animal breeding programs in livestock. In this study was found no relation between the $E R \alpha$ gene polymorphisms and milk production traits. The statistica analyses could be influenced by rare occurrences of the ER $\alpha / S n a B I$ AA and $E R \alpha / B g l I$ GG genotypes and low total numbers of analysed individuals. For further investigation of these polymorphic sites will be necessary the involvement of other dairy cattle breeds and increase of animal numbers. Generally the analyses of production traits genetic background of cattle are difficult because these quantitative and qualitative traits are not affected only by one major gene
Therefore it would be appropriate to analyse multiple genes simultaneously in population.

Acknowledgments: This work has been supported by the the Slovak Research and Development Agency under the contract No. APVV-0636-11 and No. LPP0220-09.

\section{REFERENCES}

CLARKE, R. 2000. Introduction and overview: sex steroids in the mammary Gland. Journal of Mammary Gland Biology and Neoplasia. 2000, 5, 245-250. http:// 10.1023/A:1009527609611

GÁBOR, M. 2009. Genetic markers of meat quality in cattle and sheep. Nitra: SPU, 98.

JAKIMIUK, A., NOWICKA, M., BOGUSIEWICZ, M., ADAMIAK, A., SKORUPSKI, P., MIOTLA, P., RECHBERGER, T., HACZYNSKI, J. 2007 Prevalence of estrogen receptor $\alpha$ PvuII and XbaI polymorphism in population of Polish postmenopausal women. Folia Histochemica et Cytobiologica, 2007, 45, 331-338. http://10.5603/4504

JEDRZEJCZAK, M.W., GRZESIAK, W., SZATKOWSKA, I., DYBUS, A. MUSZYŃSKA, M., ZABORSKI, D. 2011. Association between polymorphisms of CYP19, CYP21 and ER1 genes and milk production traits in Black-and-White cattle. Turkish Journal of Veterinary and Animal Science, 35, 41-49. http://10.3906/vet-0911-205

KMIEĆ, M., DVOŘÁK, J., VRTKOVÁ, I. 2002. Study on a relation between estrogen receptor (ESR) gene polymorphism and some pig reproduction performance characters in Polish Landrace breed. Czech Journal of Animal Science, 2002, 47, 189-193.

LI, R.W., MEYER, M.J., VAN TASSELL, C.P., SONSTEGARD, T.S. 2006 Identification of estrogen responsive genes in the parenchyma and fat pad of the bovine mammary gland by microarray analysis. Physiol. Genomics, 2006, 27, 42 53. http://dx.doi.org/10.1152/physiolgenomics.00032.2006

RYBACZYK, L.A., BASHAW, M.J., PATHAK, D.R., MOODY, S.M., GILDERS, R.M., HOLZSCHU, D.L. 2005. An overlooked connection: serotonergic mediation of estrogen-related physiology and pathology. $B M C$ Women's Health, 5, 12-21. http:// 10.1186/1472-6874-5-12 
SAS Institute Inc. (2009). Administering SAS ${ }$ Enterprise Guide ${ }$ 4.2. Cary, NC: SAS Institute Inc.

SZATKOWSKA, I., GRZESIAK, W., JÊDRZEJCZAK, M., DYBUS, A., ZABORSKI, D., JANKOWIAK, D. 2011. An analysis of CYP19, CYP21 and ER genotypes in Polish Holstein-Friesian cows with regard to the selected reproductive traits. Acta Veterinaria Brno, 80, 65-71. http://dx.doi.org/10.2754/avb201180010065

SZREDER, T., ELAZOWSKA, B.Z., ZWIERZCHOWSKI, L., PAREEK, CH.S 2007. A novel nucleotide sequence polymorphism in the 5 '-noncoding region of bovine estrogen receptor $\alpha$ gene, the RFLP-SnaBI. Biochemical Genetics, 45, 255-262. http://dx.doi.org/10.1007/s10528-006-9072-8

SZREDER, T., ZWIERZCHOWSKI, L. 2004a. Polymorphism within the bovine estrogen receptor- $\alpha$ gene 5 '-region. Journal of Applied Genetics, 45, 225-236.

SZREDER, T., ZWIERZCHOWSKI, L. 2004b. RFLP - TspRI polymorphism within exon 1 of the bovine estrogen receptor- $\alpha(\mathrm{ER} \alpha)$ gene. Animal Science Papers and Reports, 22, 543-549.

SZREDER, T., OPRZACDEK, O., ŻELAZOWSKA, B., DYMNICKI, E. ZWIERZCHOWSKI, L. 2011. Polymorphism A/C in exon 7 of the bovine estrogen receptor $\alpha(\mathrm{ER} \alpha)$ gene and its association with functional and milk production traits in Red-and-White cattle. Animal Science Papers and Reports, 29(4), 281-291.

YEH, F.C., YANG, R., BOYLE, T.J., YE, Z., XIYAN, J.M. 2000. PopGene32, Microsoft Windows based freeware for population genetic analysis, version 1.32. Mol. Biol. Biotechnol. Centre, Univ. Alberta, Edmonton, Alberta, Canada.

ZAHMATKESH, A. RAHMANI, H., EDRISS, M.A., TABATABAEI, B.E.S 2011. Bovine ER- $\alpha$ polymorphism in relation with production traits. In 2011 International Conference on Food Engineering and Biotechnology IPCBEE. Singapore : IACSIT Press, 2011, s. 250-254.

ZAHMATKESH, A. RAHMANI, H., EDRISS, M.A., TABATABAEI, B.E.S 2012. Estrogen receptor $\alpha(E R-\alpha)$ gene and bovine performance: is there any relation?. Animal Science Papers and Reports, 30(4), 373-381. 